\title{
TANGGUNG JAWAB MUTLAK PENJUAL AKIBAT PRODUK CACAT TERSEMBUNYI DALAM TRANSAKSI JUAL BELI DARING
}

\author{
Banu Ariyanto \\ Program Pascasarjana Magister Hukum, Universitas Sebelas Maret|banuariyanto@gmail.com \\ Hari Purwadi \\ Program Pascasarjana Fakultas Hukum, Universitas Sebelas Maret|hpurwadie@gmail.com \\ Emmy Latifah \\ Program Pascasarjana Fakultas Hukum, Universitas Sebelas Maret|emmy.latifah@yahoo.com
}

\author{
A R T I C L E I N F O \\ Article history: \\ Received \\ 23 November 2020 \\ Revised \\ 26 Maret 2021 \\ Accepted \\ 6 Desember 2021
}

Kata-kata Kunci: Tanggung jawab mutlak; Penjual; Produk cacat tersembunyi.

\section{Keywords:}

\section{Absolute} responsibility; Sales; Product hidden defect.

\begin{abstract}
Abstrak
Penawaran barang dengan media daring dilakukan oleh penjual dengan mengandalkan deskripsi barang dalam bentuk video atau foto sehingga konsumen tidak dapat melakukan pengecekan secara langsung atas barang yang akan dibelinya. Disamping kewajiban konsumen untuk berhati-hati, konsumen juga perlu mendapatkan perlindungan. Artikel ini menganalisis tanggung jawab penjual akibat produk cacat tersembunyi dalam transaksi jual beli secara daring. Penulis berpendapat bahwa produk cacat tersembunyi yang dijual oleh penjual dalam transaksi daring menjadi tanggung jawab mutlak penjual sebagaimana diatur pada Pasal 19 UUPK, serta ketentuan Pasal 1365 dan 1865 KUH Perdata, yaitu penjual bertanggung jawab atas barang yang dijual. Namun tanggung jawab tersebut harus dibuktikan bahwa penjual memang berbuat kesalahan, dan akibat kesalahan tersebut telah merugikan konsumennya.
\end{abstract}

\begin{abstract}
The seller offers goods with online media by relying on the description of the goods in videos or photos so that consumers cannot directly check the goods to be purchased. Despite the consumer duty to be aware, consumers need protection as well. The article analyzes sellers' responsibilities due to hidden defects in online buying and selling transactions. The author concludes that hidden defective products sold by sellers in online transactions are the absolute responsibility of the sellers as regulated in Article 19 of the Customer Protection Law and the provisions of Articles 1365 and 1865 of the Civil Code, the seller is responsible for the goods sold. However, the seller's error must be proven, and the consequences of the error have been detrimental to the consumer.
\end{abstract}




\section{PENDAHULUAN}

Artikel ini merupakan pembahasan lanjutan dari artikel yang berjudul "Perlindungan Konsumen Akibat Produk Cacat Tersembunyi Dalam Transaksi Jual Beli Online" yang telah dimuat dalam Prosiding. ${ }^{1}$ Artikel pada prosiding menjelaskan tentang adanya perlindungan hukum bagi pembeli atas produk dengan cacat tersembunyi yang menjadi tanggung jawab penjual dalam jual beli daring. Sementara artikel ini khusus mendiskusikan tentang prinsip tanggung jawab mutlak penjual atas produk dengan cacat tersembunyi dalam jual beli daring.

Proses jual beli daring pada dasarnya tidak berbeda dengan jual beli pada umumnya. Media utama dalam jual beli daring adalah internet. Saat ini telah banyak bermunculan toko-toko online dan sebagai implikasinya masyarakat banyak yang beralih yang melakukan jual beli daring. Melalui toko online, pengusaha atau penjual yang menawarkan barang dengan mengandalkan deskripsi barang dengan video atau foto, dan konsumen tidak dapat melakukan pengecekan secara langsung atas barang yang akan dibelinya. Hal ini membuat banyak konsumen sering kali dirugikan, karena barang yang dibeli tidak sesuai antara deskripsi dengan kondisi nyata barang. ${ }^{2}$

Menurut data Yayasan Lembaga Konsumen Indonesia (YLKI) dari tahun 2016 sampai 2018 terdapat peningkatan jumlah pengaduan terkait jual beli daring. Dari data tersebut, banyak konsumen sering kali dirugikan oleh pihak penjual. Dari data tahun 2016 sejumlah 33 pengaduan, tahun 2017 sejumlah 101 pengaduan dan di tahun 2018 sejumlah 130 pengaduan terkait kasus belanja daring. ${ }^{3}$ Sedangkan data yang diperoleh dari Direktorat Tindak Pidana Siber Bareskrim Polri, jumlah laporan penipuan online dari tahun 2015 sampai 2019 fluktuatif dan selalu ada, yang jumlahnya tidak sedikit. Rinciannya, pada tahun 2015 sebanyak 1.494 kasus, tahun 2016 sebanyak 1.570 kasus, tahun 2017 sebanyak 1.430 kasus, tahun 2018 sebanyak 1.781 kasus dan tahun 2019 sebanyak 1.430 kasus. ${ }^{4}$ Dari jumlah kasus tersebut, permasalahan yang dominan adalah barang yang dibeli konsumen tidak sesuai yang diharapkan karena terdapat cacat tersembunyi.

Fokus utama artikel ini adalah perlindungan konsumen (pembeli) dalam jual beli daring, di mana yang menjadi isu sentral adalah perlindungan hukum atas produk dengan cacat tersembunyi di mana pihak penjual harus bertanggung jawab atas kerugian yang dialami oleh konsumen. Tanggung jawab ini berkaitan dengan tanggung jawab produk (Product Liability). Dalam tanggung jawab produk, asas atau prinsip yang ingin didiskusikan adalah tanggung jawab mutlak (strict liability) dari

Banu Ariyanto, 'Perlindungan Konsumen Akibat Produk Cacat Tersembunyi dalam Transaksi Jual Beli Online' (Seminar Nasional \& Call For Paper UNS 2018: Pembangunan Hukum Nasional dan Hak Asasi di Bidang Sumber Daya Alam dalam Rangka Membangun Negara Indonesia yang Sejahtera 2018) 415-431.

Ibid.

Pramdia Arhando Julianto, 'Toko Online Paling Banyak Diadukan Konsumen ke YLKI, Ini Daftarnya' (Kompas, 19 Januari 2020) <https://ekonomi.kompas.com/read/2018/01/19/1717 $56726 /$ toko-online-paling-banyak-diadukan-konsumen-ke-ylki-ini-daftarnya?page=all> accessed 10 Juli 2020.

4 Agustin Setyo Wardani, 'Marak Penipuan Online Shop di Medsos, Hati-Hati Modusnya Makin Canggih' (Liputan6, 17 Januari 2020) <https://www.liputan6.com/tekno/read/4157301/ head line-marak-penipuan-online-shop-di-medsos-hati-hati-modusnya-makin-canggih> accessed 10 Juli 2020. 
penjual kepada pembeli. Prinsip tanggung jawab tersebut akan lebih memberikan perlindungan konsumen dalam jual beli daring di era globalisasi ini karena penjual merupakan perpanjangan tangan dari produsen. ${ }^{5}$

Konsumen perlu mendapatkan perlindungan karena, menurut Edmon Makarim, konsumen lebih banyak memiliki resiko daripada penjual. ${ }^{6}$ Hak-hak konsumen sangat rentan karena posisi tawar konsumen yang lemah dan sangat riskan untuk dilanggar oleh penjual, ${ }^{7}$ sehingga diperlukan pertanggungjawaban mutlak penjual. Dharu Triasih, B. Rini Heryanti, dan Endah Pujiastuti menambahkan bahwa meski perlindungan hukum bagi konsumen dalam perjanjian jual beli daring diatur dalam Undang-Undang Nomor 8 Tahun 1999 tentang Perlindungan Konsumen (UUPK), Undang-Undang Nomor 11 tahun 2008 tentang Informasi dan Transaksi Elektronik, dan Kitab Undang-Undang Hukum Perdata (KUH Perdata) sebagai induk dari hukum perjanjiannya, tetapi pengaturan tersebut belum dapat memberikan perlindungan hukum secara optimal bila terjadi kecurangan dari penjual, baik itu tentang cacat produk, informasi yang tidak jujur maupun keterlambatan pengiriman barang. ${ }^{8}$

Ekspektasi dari penerapan prinsip tanggung jawab mutlak terhadap produk dengan cacat tersembunyi dalam jual beli daring adalah mendorong supaya penjual menjual produknya dengan jujur. Hal ini bertujuan untuk mengantisipasi terjadinya kerugian yang dialami konsumen. Atas dasar itu, sistematika pembahasan artikel ini dapat dijelaskan sebagai berikut. Pertama, akan dibahas terlebih dahulu karakteristik jual beli daring untuk memberikan pemahaman awal mengenai kekhususannya. Selanjutnya akan dilakukan pembahasan mengenai prinsipprinsip pertanggungjawaban dalam perlindungan konsumen (pembeli) dalam jual beli daring; dan terakhir mengenai tanggung jawab mutlak penjual dalam jual beli secara daring dikaitkan dengan isu tentang produk yang mengandung cacat tersembunyi.

\section{PEMBAHASAN}

\section{Karakteristik Jual Beli Daring}

Perdagangan elektronik merupakan model transaksi dengan karakteristik yang berbeda dengan perdagangan konvensional. Daya jangkaunya tidak hanya lokal tapi juga bersifat global sehingga dalam transaksi elektronik atau e-commerce jika terdapat permasalahan maka dapat menggunakan instrumen undang-undang informasi dan transaksi elektronik dan Peraturan Pemerintah Nomor 82 Tahun 2012 tentang Penyelenggaraan Sistem dan Transaksi Elektronik. ${ }^{9}$ Pelaksanaan transaksi e-commerce yang berkembang pesat harus diimbangi dengan adanya pengawasan yang tegas dalam setiap implementasinya. Pengawasan transaksi e-commerce

Fitriah, 'Tanggung Jawab Produk Dalam Transaksi E-Commerce' (2021) 19 (1) Solusi 118, 124125

Abdul Halim Barkatullah, Hak-hak Konsumen (Nusamedia 2010) 1.

Ibid.

Dharu Triasih, B.Rini Heryanti, dan Endah Pujiastuti, 'Optimalisasi Perlindungan Hukum Bagi Konsumen Dalam Perjanjian Jual Beli Online' (2019) 9 (2) Humani: Hukum dan Masyarakat Madani 193, 201.

Rizka Syafriana, 'Perlindungan Konsumen Dalam Transaksi Elektronik' (2016) 1 (2) De Lega Lata 430, 443. 
memang tidak semudah ketimbang melakukan pengawasan terhadap transaksi perdagangan konvensional. Kementerian Perdagangan (Kemendag) selaku Pembina sektor perdagangan, mewajibkan seluruh produk atau barang yang diperdagangkan melalui toko online (e-commerce) harus memenuhi Standar Nasional Indonesia (SNI) dan kewajiban pencantuman label berbahasa Indonesia. Fungsi pengawasan dari legislator serta masyarakat sebagai konsumen yang cerdas karena karakteristik perdagangan e-commerce yang berbeda dengan perdagangan konvensional. ${ }^{10}$

Pada jual beli online, pembeli mengamati barang yang akan dibeli melalui gambar yang dipasang dan didekripsikan oleh penjual. Untuk itu, penjual harus mendeskripsikan secara teliti atas barang tersebut, dan memastikan dengan panca inderanya bahwa barang tersebut tidak cacat, serta tidak menutupi atau tidak menyembunyikan adanya kecacatan suatu barang yang dijual. Intinya, menjamin bahwa sepanjang sepengetahuan penjual bahwa barang tidak ada cacat baik yang kelihatan atau cacat yang tersembunyi (tidak terlihat panca indera). Setelah barang dipesan pembeli, maka penjual akan mengemas dan menyerahkan barang tersebut untuk dikirim melalui jasa ekspedisi. Jadi, apabila barang rusak atau cacat akibat proses pengiriman, bukan menjadi tanggung jawab penjual.

Berkaitan dengan tanggung jawab mutlak penjual tersebut, maka penjual dilarang menjual produk cacat tersembunyi. Pada transaksi jual beli daring, posisi pembeli berada pada posisi yang lemah. Hal ini dikarenakan saat melakukan pembelian barang, pembeli tidak dapat melakukan pengecekan terlebih dahulu terhadap barang yang mau dibelinya secara langsung melalui panca indera, tetapi pembeli hanya dapat mengamati berdasarkan gambar yang dipasang oleh penjual. Mengacu pada KUH Perdata Pasal 1505. "si Penjual tidaklah diwajibkan menanggung terhadap cacat yang kelihatan, yang dapat diketahui sendiri oleh si Pembeli." Pada kondisi ini, pembelilah yang bertanggung jawab dan tidak mendapatkan perlindungan hukum. Namun apabila barang yang dibeli terdapat cacat tersembunyi, maka penjual harus bertanggung jawab. Hal ini sesuai Pasal 1504 KUH Perdata yang menentukan bahwa "penjual selalu diharuskan untuk bertanggung jawab atas adanya cacat tersembunyi dalam hal demikian".

Mengacu Pasal 1505 dan 1504 KUH Perdata di atas, maka ada beberapa kemungkinan, yaitu: (1) penjual mengetahui bahwa barang yang dijual terdapat cacat tersembunyi dan tidak memberitahukan kepada calon pembeli; (2) penjual mengetahui bahwa barang yang dijual terdapat cacat tersembunyi dan memberitahukan kepada calon pembeli; (3) penjual tidak mengetahui bahwa barang yang dijual terdapat cacat tersembunyi. Sehubungan dengan adanya berbagai kemungkinan tersebut, maka bentuk tanggung jawab yang harus ditanggung oleh penjual mestinya juga berbeda. ${ }^{11}$

\section{Tanggung Jawab Mutlak Penjual}

Prinsip tanggung jawab mutlak dinyatakan sebagai bentuk tanggung jawab suatu produk didasarkan pada pengembangan doktrin perbuatan melanggar hukum seperti tercantum pada Pasal 1365 KUH Perdata. Oleh karena itu, di era globalisasi 
saat ini, perhatian yang lebih harus diberikan pada perlindungan konsumen. Tanggung jawab produk (product liabilty) menurut Hurs adalah "product liabilty is the liabilty of manufacturer, processor or non-manufacturing seller for injury to the person property of a buyer and third party, caused by product which has been sold", 12 yang artinya tanggung jawab produk adalah tanggung jawab dari produsen produk, pengolah ataupun pihak yang terlibat proses produk termasuk penjual atas cidera yang dialami pembeli dan pihak ketiga, yang disebabkan oleh produk yang telah dijual.

Menurut Nurmadjito tanggung gugat produk merupakan terjemahan bebas dari istilah product liability, yaitu suatu konsepsi hukum yang memberikan perlindungan kepada konsumen dengan cara membuktikan bahwa kerugian konsumen timbul akibat kesalahan dalam proses produksi dan berhak untuk mendapatkan ganti rugi. ${ }^{13}$ Konsepsi tanggung gugat produk secara umum tidak jauh berbeda dengan konsepsi tanggung jawab seperti diatur dalam Pasal 1365 dan Pasal 1865 KUH Perdata. Perbedaannya yaitu tanggung jawab produsen untuk memberikan ganti rugi diperoleh setelah pihak yang dirugikan dapat membuktikan bahwa cacat produk dan kerugian disebabkan oleh kesalahan produsen. Selain itu, ketentuan tersebut tidak secara tegas mengatur pemberian ganti rugi atau beban pembuktian kepada konsumen, melainkan kepada pihak yang mempunyai hubungan hukum dengan produsen, seperti: konsumen, sesama produsen atau penyalur, pedagang atau instansi lain, sehingga materi tanggung gugat produk merupakan doktrin hukum baru untuk memperkaya khasanah dalam sistem hukum yang berlaku di Indonesia. ${ }^{14}$ Oleh karena itu, product liability merupakan tanggung jawab secara hukum dari orang atau badan yang menghasilkan suatu produk, atau dari orang atau badan yang menjual atau mendistribusikan produk. Konvensi ini diperluas terhadap orang atau badan yang terlibat dalam rangkaian komersial persiapan dan distribusi produk, termasuk pengusaha bengkel dan pergudangan, serta agen dan pekerja dari badan-badan usaha tersebut. 15

Tanggung jawab mutlak harus dipenuhi oleh produsen atau penjual apabila telah mengakibatkan kerugian konsumen. Penjual atau produsen memiliki kewajiban ikut serta menciptakan iklim usaha yang sehat demi menunjang kemajuan ekonomi nasional. Untuk itu, penjual memiliki tanggung jawab untuk dapat melindungi konsumennya, dengan cara mematuhi dan menjunjung tinggi kebiasaan yang berlaku di kalangan dunia usaha. Etika bisnis harus tetap dipegang kuat oleh para produsen atau penjual dalam rangka memberikan peran penting untuk meningkatkan pembangunan nasional Indonesia. ${ }^{16}$

Penjual memiliki kewajiban untuk senantiasa beritikad baik dalam melakukan usaha sebagaimana diatur dalam Pasal 7 huruf a UUPK. Penjual harus bertanggung jawab untuk menciptakan iklim usaha yang sehat demi kemajuan pembangunan

12 Diederick-Verschoor, 'Similarities and Differences between Air and Space Law, Primarily in the Field of Private International Law' dalam Holijah, 'Pengintegrasian Urgensi dan Eksistensi Tanggung Jawab Mutlak Produk Barang Cacat Tersembunyi Pelaku Usaha Dalam UndangUndang Perlindungan Konsumen di Era Globalisasi' (2014) 14 (1) Jurnal Dinamika Hukum 176, 181.

13 Rajagukguk dkk (n 11) 22.

Rajagukguk dkk (n 11) 23.

Rajagukguk dkk (n 11) 46.

Verschoor (n 12). 
nasional. Sebenarnya ada beberapa ketentuan di dalam UUPK yang bertujuan mengarahkan penjual agar berperilaku sehat demi kesuksesan pembangunan ekonomi nasional, khususnya pada bidan usaha. Untuk itu, setiap pelanggaran yang dilakukan oleh penjual, maka dapat dikenakan sanksi hukum atas pelanggaran yang dilakukan. Upaya menciptakan iklim usaha sehat membutuhkan keseriusan dan ketegasan. Oleh karena itu, setiap pelanggaran yang dilakukan oleh penjual harus diberikan sanksi. Pemberian sanksi ini penting untuk menciptakan iklim usaha yang sehat. Sanksi merupakan salah satu alat untuk menegakkan disiplin sekaligus sebagai alat preventif bagi pengusaha lainnya agar tidak melakukan perbuatan yang sama.

Klaim atau tuntutan tanggung jawab produk dari penjual didasarkan pada halhal seperti: pelanggaran (breach of warranty), tanggung jawab mutlak (strict liabiality), dan kelalaian (negligence). ${ }^{17}$ Tanggung jawab mutlak penjual atas produk akibat cacat tersembunyi merupakan tanggung jawab atas produk cacat tersembunyi yang telah dijual kepada konsumen dan menimbulkan kerugian. Tanggung jawab ini merupakan prinsip tanggung jawab mutlak penjual, yaitu tanggung jawab yang tidak didasarkan atas kesalahan sebagai unsur yang menentukan beban pembuktian terbalik penjual, yang meminta penjual secara moral dan hukum bertanggung jawab atas produk yang telah dijualnya. Namun, tanggung jawab ini berkaitan karena hal tersebut telah merugikan pihak konsumen. ${ }^{18}$ Tanggung jawab mutlak pada penjual ini terkait dengan produk cacat tersembunyi yang telah menyebabkan konsumen dirugikan. Hal ini sudah menjadi konsekuensi dari bentuk risiko dari penjual atas produk yang dijualnya.

Berkaitan dengan tanggung jawab, maka hal ini tidak bisa lepas dari prinsipprinsip sebuah tanggung jawab itu sendiri. Prinsip tanggung jawab merupakan hal yang sangat penting dalam perlindungan konsumen. Prinsip tanggung jawab dalam hukum dapat dibedakan, menjadi: 19

1) Liability based of fault (prinsip tanggung jawab berdasarkan kesalahan), yaitu prinsip yang menyatakan bahwa seseorang baru dapat diminta bertanggung jawab di hadapan hukum apabila ada unsur kesalahan yang telah dilakukan.

2) Presumption of libiality (prinsip praduga untuk selalu bertanggung jawab), yaitu prinsip yang menyatakan bahwa tergugat dianggap bertanggung jawab hingga dirinya dapat membuktikan bahwa ia tidak melakukan kesalahan. Beban pembuktian ini ada pada penggugat atau dikenal dengan sistem pembuktian terbalik.

3) Presumption of non liability (prinsip praduga untuk tidak selalu bertanggung jawab), yaitu prinsip ini merupakan kebalikan dari pernyataan prinsip praduga selalu bertanggung jawab, dan tergugat selalu dianggap tidak bertanggung jawab hingga ada bukti bahwa ia berbuat kesalahan.

17 Andrew Carl Spacone, 'The Emergency of Strict Laibility: A Historical Perspective and Other Consideration Including Senate 100' dalam Holijah, 'Pengintegrasian Urgensi dan Eksistensi Tanggung Jawab Mutlak Produk Barang Cacat Tersembunyi Pelaku Usaha Dalam UndangUndang Perlindungan Konsumen di Era Globalisasi' (2014) 14 (1) Jurnal Dinamika Hukum 176, 183.

18 Ibid.

19 Innosentius Samsul, Perlindungan Konsumen, Kemungkinan penerapan Tanggung Jawab Mutlak (FH Pascasarjana UI 2004) 48. 
4) Strict liability (prinsip tanggung jawab mutlak), yaitu prinsip yang menyamakan dengan tanggung jawab absolut (absolute liability).

5) Limitation of liability (prinsip tanggung jawab dengan pembatasan), yaitu prinsip tanggung jawab sebagaimana klausul eksonerasi yang tercantum dalam perjanjian standar yang dibuat oleh produsen atau penjual. Namun, prinsip tanggung jawab ini dapat merugikan konsumen apabila ditetapkan secara sepihak oleh produsen atau penjual. Padahal pada UUPK, penjual tidak dibenarkan secara sepihak untuk menentukan klausul yang berkaitan dengan tanggung jawabnya.

\section{Prinsip Tanggung Jawab berdasarkan Kesalahan (Libiality Based on Fault)}

Pada prinsip tanggung jawab yang didasarkan atas kesalahan (liability based on fault) ini, prinsip tanggung jawab ini secara umum berlaku berdasarkan hukum pidana dan perdata. Pasal 1365, Pasal 1366 dan Pasal 1367 KUH Perdata dinyatakan bahwa seseorang baru dapat diminta untuk bertanggung jawab secara hukum apabila ia telah melakukan kesalahan. ${ }^{20}$ Tanggung jawab berdasarkan kesalahan (negligence) merupakan suatu prinsip tanggung jawab yang sifatnya subjektif, yaitu merupakan bentuk tanggung jawab yang ditentukan oleh penjual atau produsen. Bentuk sifat subjektif ini menyarankan kepada penjual untuk bersikap berhati-hati dalam menjual produk agar tidak merugikan konsumen. ${ }^{21}$

1. Prinsip praduga untuk selalu bertanggung jawab (presumption of libiality), yaitu prinsip yang menyatakan bahwa tergugat dianggap bertanggung jawab hingga dirinya dapat membuktikan bahwa ia tidak melakukan kesalahan. ${ }^{22}$

2. Prinsip praduga untuk tidak selalu bertanggung jawab (presumption of non liability), yaitu prinsip yang merupakan kebalikan dari pernyataan prinsip praduga selalu bertanggung jawab, dan tergugat selalu dianggap tidak bertanggung jawab hingga ada bukti bahwa ia berbuat kesalahan. Jadi tanggung jawab hanya dalam lingkup transaksi konsumen yang terbatas, selama pembatasan tersebut secara commense dapat dibenarkan. ${ }^{23}$

3. Prinsip Tanggung Jawab Mutlak (strict liability), yaitu prinsip yang menyatakan bahwa kesalahan tidak sebagai faktor yang menentukan. Namun ada pengecualian yang memungkinkan untuk dapat dibebaskan dari tanggung jawab akibat keadaan force majeur. ${ }^{24}$

Tanggung jawab mutlak (strict liability) berhubungan dengan klausal antara subjek yang bertanggung jawab dengan kesalahan yang telah diperbuat. Tanggung jawab ini dalam perspektif hukum perlindungan konsumen digunakan untuk menjerat para penjual yang dianggap merugikan konsumen, dan prinsip ini dikenal dengan istilah product liability.

Prinsip ini menegaskan bahwa produsen atau penjual bertanggung jawab terhadap kerugian yang dialami oleh konsumen atas penggunaan produk. Gugatan product liability dapat dilakukan berdasarkan 3 (tiga) hal yaitu: (a) ada unsur kelalaian; (b) breach of warranty (melanggar jaminan); dan (c) strict liability (tanggung

Shidarta, Hukum Perlindungan Konsumen Indonesia (Grasindo 2004) 24.

Samsul, Perlindungan Konsumen, Kemungkinan penerapan Tanggung Jawab Mutlak (n 19) 7.

Shidarta (n 20) 75 .

Shidarta (n 20) 77 .

Shidarta (n 20) 78. 
jawab mutlak). Apabila ada hubungan perjanjian antara konsumen dengan penjual, dan prestasi pemberi jasa tidak dapat terukur serta merupakan perjanjian ikhtiar, maka bentuk tanggung jawab penjual akan didasarkan tanggung jawab profesional, yaitu bentuk tanggung jawab perdata secara langsung atau strict liability dari penjual yang telah menyebabkan kerugian pada konsumen. Namun, jika terdapat hubungan perjanjian antara penjual dengan konsumen, dan prestasi pemberi jasa tersebut tidak terukur dan merupakan perjanjian hasil, maka bentuk tanggung jawab penjual didasarkan atas tanggung jawab profesional, yaitu bentuk tanggung jawab perdata atas perjanjian kontrak yang telah dibuat.

\section{Prinsip Pembatasan Tanggung Jawab (Limitation of Libiality)}

Prinsip pembatasan tanggung jawab ini biasanya dicantumkan pada penjual sebagai bentuk klausul eksonorasi dalam perjanjian standar, dengan tujuan untuk membatasi nilai ganti rugi. Pada pelaksanaannya, prinsip tanggung jawab dengan pembatasan ini dikombinasikan dengan prinsip tanggung jawab secara umum. Pada hukum perlindungan konsumen, prinsip tanggung jawab mutlak (product liability) digunakan untuk menjerat penjual atau produsen yang menjual barang yang dapat merugikan konsumen.

Product liability telah diatur pada KUH Perdata pada Pasal 1322, Pasal 1473, Pasal 1474, Pasal 1491, Pasal 1504, dan Pasal 1511. Namun KUH Perdata tidak mengatur secara lebih rinci dan khusus seperti UUPK. Pada KUH Perdata diatur mengenai tindakan atau perbuatan melanggar hukum, yaitu jika ada seseorang melakukan tindak perbuatan melanggar hukum, maka kepada orang tersebut diwajibkan untuk memberi ganti rugi kepada orang yang telah dirugikan. Pada Pasal 1365 KUH Perdata dinyatakan bahwa ada empat syarat jika suatu perbuatan tersebut dapat dimasukkan dalam kualifikasi perbuatan melanggar hukum, yaitu:25

1) Ada tindakan atau perbuatan melanggar hukum, yang berupa tindakan atau perbuatan melanggar hak orang lain, melakukan perbuatan bertentangan dengan kewajiban hukum, melanggar kesusilaan, dan kurang bersikap berhati-hati yang seharusnya dilakukan dalam pergaulan di masyarakat terhadap diri atau benda milik orang lain. ${ }^{26}$

2) Terdapat unsur kesalahan, seperti: (a) perbuatan yang dilakukan dapat dinyatakan dapat disesalkan; (b) perbuatan itu dapat diduga akibatnya, yaitu: secara objektif bahwa sebagai manusia normal ia dapat menduga akibat yang akan timbul, secara subjektif bahwa sebagai seorang ahli dapat menduga akibat yang akan timbul; (c) perbuatan tersebut dapat dipertanggungjawabkan, yaitu ia dalam keadaan yang cakap. ${ }^{27}$

3) Terdapat kerugian yang ditimbulkan. Nieuwenhuis mengartikan kerugian sebagai berkurangnya harta kekayaan seseorang yang disebabkan oleh tindakan atau perbuatan orang lain (melakukan atau membiarkan) yang

Dian Afrilia dan Helena Primadianti Sulistyaningrum, 'Implementasi Prinsip Strict Liability (Prinsip Tanggung Jawab Mutlak) dalam Penyelesaian Sengketa Konsumen' (2017) 24 (3) Simbur Cahaya 4949, 4960.

26 Ahmadi Miru dan Sutarman Yodo, Hukum Perlindungan Konsumen (Grafindo Persada 2014$) 130$.

27 Purwahid Patrick, Dasar-dasar Hukum Perikatan (Perikatan yang Lahir dari Perjanjian dan Undang Undang) (Mandar Maju 2014) 10-11. 
dianggap melanggar norma.28 Secara garis besar, kerugian yang dialami seseorang dapat digolongkan menjadi dua, yaitu kerugian yang telah menimpa diri, dan kerugian yang berkaitan dengan harta benda seseorang. Kerugian harta benda ini dapat berupa kerugian secara nyata dan kehilangan dari yang diharapkan. ${ }^{29}$

4) Terhadap hubungan sebab akibat (kausalitas) antara kesalahan dengan kerugian yang ditimbulkan. Pada prinsip ini lebih mengedepankan keadilan, yaitu seseorang yang telah berbuat salah yang telah dinyatakan dengan buktibukti yang cukup kuat, maka ia harus mengganti kerugian kepada pihak korban. Namun apabila bukti-bukti dinyatakan tidak cukup kuat, maka ia tidak harus mengganti kerugian.

Keempat unsur di atas harus dapat terpenuhi, karena unsur-unsur tersebut bersifat menyeluruh dan saling berkaitan antara satu dengan lainnya. Artinya, apabila terdapat satu unsur yang tidak terpenuhi maka orang yang diduga berbuat salah dapat terlepas dari jeratan tanggung jawab hukum. Untuk itu, konsumen harus memiliki bukti-bukti yang kuat bahwa penjual benar-benar telah melakukan kesalahan dan merugikan dirinya. Pembuktian ini terkadang membuat konsumen merasa kesulitan untuk dapat membuktikan kesalahan yang telah diperbuat oleh penjual. Oleh karena itu, walaupun UUPK telah mengatur strict liability, dalam hal ini product liability, namun kenyataannya dalam penerapan di masyarakat, prinsip product liability dan strict liability masih kurang efektif dalam upaya memberikan perlindungan hukum kepada konsumen. Hal ini karena prinsip tanggung jawab mutlak pada penjual untuk bertanggung jawab atas kerugian yang dialami oleh konsumen, semestinya konsumen tidak harus membuktikan bahwa penjual telah berbuat kesalahan, dan mestinya tanggung jawab ini harus bersifat melekat pada penjual. ${ }^{30}$

\section{Tanggung Jawab Penjual atas Produk Cacat Tersembunyi}

Kemajuan teknologi komputer dan internet telah memberikan perkembangan yang cukup pesat terhadap jual beli daring, sehingga konsumen dapat berbelanja dari rumah tanpa harus ke luar rumah. Selain itu, berbagai pilihan produk (barang dan jasa) yang ditawarkan oleh penjual cukup beragam dengan harga yang relatif murah. Hal ini memunculkan tantangan yang bersifat positif dan negatif. Tantangan bersifat positif berkaitan dengan kemudahan konsumen untuk memilih produk yang diinginkan tanpa harus datang ke tempat penjual, tetapi cukup dengan fasilitas internet, sedangkan tantangan negatifnya adalah menyebabkan posisi konsumen yang semakin lemah di hadapan penjual, karena produk yang akan dibeli konsumen tidak dapat dicek terlebih dahulu secara langsung, sehingga apabila cacat tersembunyi hal ini dapat merugikan konsumen. ${ }^{31}$

Pada UUPK saat ini secara definitif belum ada pasal yang memuat tentang produk barang cacat, khususnya tentang produk barang cacat tersembunyi. Walaupun secara implisit dapat ditafsirkan dari Pasal 19 ayat (1) bahwa pelaku

\footnotetext{
28 Djasadin Saragih (tjm), Pokok-pokok Hukum Perikatan (Universitas Airlangga 2005) 57.

29 Miru, Yodo (n 26) 133.

$30 \quad$ Afrilia, dan Sulistyaningrum (n 25) 4952.

31 Happy Susanto, Hak-hak Konsumen Jika Dirugikan (Visi Media 2008) 3.
} 
usaha bertanggung jawab memberikan ganti kerugian atas kerusakan, pencemaran, dan/atau kerugian konsumen akibat mengonsumsi barang dan/atau jasa yang dihasilkan atau diperdagangkan. Pada Pasal 19 ayat (1) UUPK ini, kata "kerusakan" terdapat kemungkinan penafsiran hukum yang bersifat argumentum analogi, ${ }^{32}$ yaitu dapat dipersamakan memiliki makna cacat tersembunyi sebagai bagian dari suatu produk yang cacat.

Produk cacat tersembunyi sesuai Pasal 1504 KUH Perdata memiliki makna bahwa suatu produk dikatakan cacat tersembunyi apabila produk yang dijual oleh penjual memiliki cacat sehingga penggunaannya tidak sesuai lagi dengan tujuan yang semestinya. Produk cacat tersembunyi ini memiliki kemungkinan, yaitu dapat diketahui oleh penjual, tidak diketahui oleh penjual, dan dapat juga tidak diketahui oleh konsumen. ${ }^{33}$ Suatu produk dikatakan cacat atau dinyatakan tidak dapat memenuhi tujuan pembuatannya, dikarenakan: ${ }^{34}$

1) Cacat produk (cacat manufaktur), yaitu kondisi produk tidak memenuhi kualitas produk, produk berada di bawah harapan konsumen, produk dapat membahayakan diri dan harta benda konsumen.

2) Cacat desain (cacat bentuk), yaitu secara bentuk atau desain produk tidak memenuhi standar yang semestinya, sehingga dapat merugikan konsumen.

3) Cacat peringatan (cacat industri), yaitu produk tidak dilengkapi informasi yang berisi peringatan atau instruksi tertentu dalam hal penggunaannya dan penyimpanannya, sehingga dapat merugikan dan membahayakan konsumen.

Berdasarkan batasan ketentuan di atas, maka tanggung jawab penjual terhadap produk cacat tersembunyi memiliki makna yang berbeda dengan tanggung jawab seperti pada umumnya. Letak tanggung jawab penjual terhadap produk cacat tersembunyi berada pada unsur bahwa produk tersebut dapat membahayakan atau merugikan konsumen atau tanggung jawab yang disebabkan karena terjadinya kerusakan atau tidak dapat berfungsinya produk itu sendiri. Kriteria produk cacat tersembunyi yang menjadi tanggung jawab penjual, yaitu:

1) Penjual mengetahui produk cacat akibat cacat manufaktur, berusaha menyembunyikan kepada konsumen, dan tetap menjualnya kepada konsumen.

2) Penjual tidak mengetahui produk cacat akibat cacat manufaktur, dan tetap menjualnya kepada konsumen.

3) Penjual mengetahui produk cacat akibat cacat desain/bentuk, berusaha menyembunyikan kepada konsumen, dan tetap menjualnya kepada konsumen.

4) Penjual tidak mengetahui produk cacat akibat cacat desain/bentuk, dan tetap menjualnya kepada konsumen.

5) Penjual mengetahui produk cacat akibat cacat peringatan (cacat industri), berusaha menyembunyikan kepada konsumen, dan tetap menjualnya kepada konsumen.

\footnotetext{
32 Sudikno Mertokusumo, Penemuan Hukum, Sebuah Pengantar (Liberty 2009) 7.

33 Holijah, 'Pengintegrasian Urgensi dan Eksistensi Tanggung Jawab Mutlak Produk Barang Cacat Tersembunyi Pelaku Usaha Dalam Undang-Undang Perlindungan Konsumen di Era Globalisasi' (2014) 14 (1) Jurnal Dinamika Hukum 176, 183, 188.

34 Celina Tri Siwi Kristiyanti, Hukum Perlidungan Konsumen (Sinar Grafika 2011) 103-104.
} 
6) Penjual tidak mengetahui produk cacat akibat cacat peringatan (cacat industri), dan tetap menjualnya kepada konsumen.

Namun penjual online tidak bertanggung jawab atas kerusakan atau cacat produk yang disebabkan oleh proses pengiriman barang dari penjual kepada konsumen akibat kesalahan pihak ekspedisi. Dengan catatan, penjual tidak termasuk dalam keenam kriteria di atas. Maksudnya, penjual sebelum mengirimkan barang telah mengecek dan memastikan bahwa barang yang akan dikirim adalah produk tidak merupakan barang cacat akibat cacat manufaktur, cacat desain/bentuk, dan cacat peringatan (cacat industri).

\section{Prinsip Presumption of Liability atas Produk Cacat Tersembunyi}

Adanya produk cacat tersembunyi yang dijual oleh penjual dalam jual beli daring merupakan tanggung jawab penjual. Hal ini berdasarkan prinsip presumption of libiality (prinsip praduga untuk selalu bertanggung jawab), yaitu prinsip yang menyatakan bahwa tergugat dianggap bertanggung jawab hingga dirinya dapat membuktikan bahwa ia tidak melakukan kesalahan. Jadi, selama penjual tidak dapat membuktikan bahwa ia tidak melakukan kesalahan, ia tetap harus bertanggung jawab atas produk yang dijual tersebut. Prinsip tanggung jawab ini mendasarkan pada sistem pembuktian terbalik. UUPK mengadopsi pembuktian terbalik ini, seperti yang ditegaskan pada Pasal 19, 22, dan 23 UUPK.

Berdasarkan Pasal 49 Peraturan Pemerintah Nomor 82 Tahun 2012 tentang Penyelenggaraan Sistem dan Transaksi Elektronik, dinyatakan bahwa pelaku usaha (penjual) memiliki kewajiban, yaitu:

1) Pelaku usaha yang menawarkan produk melalui sistem elektronik wajib menyediakan informasi yang lengkap dan benar berkaitan dengan syarat kontrak, produsen, dan produk yang ditawarkan.

2) Pelaku usaha wajib memberikan kejelasan informasi tentang penawaran kontrak atau iklan.

3) Pelaku usaha wajib memberikan batas waktu kepada konsumen untuk mengembalikan barang yang dikirim apabila tidak sesuai dengan perjanjian atau terdapat cacat tersembunyi.

4) Pelaku usaha wajib menyampaikan informasi mengenai barang yang telah dikirim.

5) Pelaku usaha tidak dapat membebani konsumen mengenai kewajiban membayar barang yang dikirim tanpa dasar kontrak.

Berdasarkan ketentuan di atas, maka konsumen perlu diberikan perlindungan hukum atas produk cacat tersembunyi yang dibelinya melalui daring, dengan cara memberikan informasi yang lengkap dan benar atas produk yang dijual, ketentuan persyaratan pembelian, ada-tidaknya jaminan (garansi) yang diberikan, prosedur dan batas waktu pengembalian barang apabila barang yang diterima konsumen tidak sesuai kesepakatan, memberitahukan proses pengiriman barang, dan melengkapi pengiriman barang dengan faktur sebagai dasar pembayaran pembelian barang pada konsumen.

Setelah diundangkannya UUPK, hal ini secara khusus telah memberikan bentuk kepastian hukum bagi perlindungan konsumen, karena permasalahan konsumen telah di atur di dalam undang-undang tersebut. Walaupun UUPK 
tersebut masih memiliki banyak kelemahan atau kekurangan, namun undang undang ini setidaknya dapat menjadi dasar pemberian perlindungan hukum bagi konsumen. Berkaitan dengan doktrin product liability dan strict liability, secara umum ada beberapa jalur perlindungan hukum yang dapat ditempuh oleh konsumen, ${ }^{35}$ seperti yang dijelaskan sebagai berikut ini.

\section{Penerapan Doktrin Product Liability}

World Trade Organization (WTO) didirikan pada tanggal 1 Januari 1995, yang kedudukannya telah menggantikan General Agreement of Tarrifs and Trade (GATT). Oleh karena itu, WTO sebagai organisasi antar pemerintah di dunia yang berfungsi mengawasi perdagangan dunia, baik perdagangan barang ataupun jasa, dan segala sesuatu yang berkaitan dengan proteksi atau perlindungan yang dianggap anti WTO atau anti liberalisasi perdagangan. Untuk itu, dalam menghadapi kondisi tersebut, negara-negara di seluruh dunia telah mempersiapkan berbagai perangkat undangundangan perlindungan konsumen.

Untuk mengantisipasi produk (barang atau jasa) yang dapat merugikan atau membahayakan konsumen, sebagian negara peserta perdagangan bebas telah menganut doktrin product liability dalam pembuatan hukum perlindungan konsumen, seperti: Amerika Serikat, Uni Eropa, dan Jepang serta negara-negara lainnya yang sudah terbiasa menjadikan hukum sebagai landasan untuk menjamin kepastian hukum yang berkeadilan sosial. Di Indonesia, terminologi product liability ada yang mengartikan sebagai istilah tanggung jawab gugat produk.

Pada UUPK, tanggung jawab pelaku usaha (penjual) terhadap kerugian yang dialami oleh konsumen secara khusus telah diatur pada Bab VI, yaitu mulai Pasal 19 sampai Pasal 28, yang dapat diklasifikasi menjadi:

1) Ada tujuh pasal, yaitu Pasal 9, 20, 21, 24, 25, dan 26 yang mengatur tentang tanggung jawab pelaku usaha.

2) Ada dua pasal, yaitu Pasal 22 dan 28 yang mengatur tantang pembuktian

3) Ada satu pasal, yaitu Pasal 23 yang mengatur tantang penyelesaian terjadinya sengketa apabila pelaku usaha tidak memenuhi kewajibannya dan memberikan ganti rugi kepada konsumen.

Berkaitan dengan ketentuan dari pasal-pasal UUPK yang disebutkan di atas, maka penjual yang tidak bertindak memenuhi ketentuan tersebut, dan dengan telah terpenuhinya unsur-unsur prinsip product liability, maka penjual dapat diproses melalui jalur hukum untuk mempertanggungjawabkan tindakannya tersebut.

\section{Penerapan Doktrin Strict Product Liability}

Terkait dengan permasalahan doktrin tanggung jawab mutlak, maka kepada penjual dapat diminta untuk bertanggung jawab atas perbuatannya sesuai intervensi pemerintah dalam pemberian jaminan hukum terhadap hak-hak konsumen, terutama berkaitan dengan keselamatan dan kesehatan, serta hak konsumen untuk mendapatkan ganti rugi, baik kerugian yang menyangkut diri

35 Yudha Hadian Nur dan Dwi Wahyuniarti Prabowo, 'Penerapan Prinsip Tanggung Jawab Mutlak (Strict Liability) Dalam Rangka Perlindungan Konsumen’ (2011) 5 (2) Buletin Ilmiah Litbang Perdagangan 177, 182 \& 195. 
pribadi konsumen (personal/bodily injury), ataupun kerusakan yang menyangkut dengan produk itu sendiri (pure economic loss). ${ }^{36}$

Terkait dengan doktrin tanggung jawab mutlak (strict product liabilty), hal ini sebenarnya berkaitan dengan tanggung jawab yang tidak didasarkan pada aspek kesalahan (fult/negligence), dan adanya hubungan kontrak (privaty of contract), tetapi tanggung jawab ini didasarkan atas produk yang cacat (object based liability) serta adanya risiko yang dapat menimbulkan kerugian pada konsumen (risk based liability). Hal ini dikarenakan bahwa tujuan dari prinsip tanggung jawab mutlak yaitu memberikan jaminan yang berkaitan dengan konsekuensi hukum dari adanya produk yang dapat mengakibatkan konsumen merasa dirugikan. ${ }^{37}$

Penerapan tanggung jawab mutlak dilatarbelakangi pemikiran bahwa tidak ada seorangpun yang sesungguhnya dapat menjamin bahwa setiap produk yang dijual $100 \%$ aman untuk dikonsumsi. Walaupun demikian, di Indonesia prinsip strict liability ini masih belum sepenuhnya. Tetapi ke depan peluang tersebut masih terbuka untuk diterapkan, karena penjual dan konsumen memiliki etiked yang sama untuk mendapatkan hak-haknya secara seimbang dalam perlindungan hukum.

Seperti yang telah tercantum dalam UUPK, penyelesaian sengketa telah diatur, yaitu dapat dilakukan melalui jalur pengadilan (ligigasi) ataupun di luar pengadilan (non litigasi). Pada Bab X Pasal 45 UUPK dinyatakan bahwa sengketa konsumen dapat diselesaikan melalui pengadilan ataupun di luar pengadilan berdasarkan pilihan sukarela para pihak. Ketentuan yang terdapat pada Pasal 45 meliputi: (a) ada kerugian yang telah diderita oleh konsumen; (b) ada gugatan yang dilakukan konsumen terhadap pelaku usaha; (c) gugatan dilakukan melalui pengadilan atau di luar pengadilan.

Pasal 48 UUPK menyatakan bahwa penyelesaian sengketa melalui jalur pengadilan harus mengacu pada ketentuan yang berlaku dalam peradilan umum dengan memperhatikan isi Pasal 45 UUPK. Lebih lanjut Pasal 48 ayat (1) menyatakan bahwa penyelesaian sengketa konsumen dapat dilakukan melalui jalur di luar pengadilan (non litigasi). Penyelesaian jalur non litigasi dapat dilakukan melalui Badan Penyelesaian Sengketa Konsumen (BPSK) sesuai arahan Pasal 49 hingga Pasal 58 UUPK. 38 Selain itu, sesuai penjelasan Pasal 45 ayat (2) dinyatakan bahwa penyelesaian sengketa di luar pengadilan (non litigasi) dapat diselesaikan dengan prinsip perdamaian berdasarkan musyawarah mufakat para pihak. Namun, penyelesaian sengketa di luar pengadilan tidak serta merta menghilangkan tanggung jawab pidana, seperti yang telah diatur pada Pasal 45 ayat (3) UUPK. Seperti dinyatakan pada Pasal 62 ayat (3) bahwa tanggung jawab pidana tetap harus dipertanggung jawabkan oleh pelaku usaha. Oleh karena itu, penjual tetap dapat diperiksa dan permasalahan dapat diselesaikan menurut ketentuan hukum pidana.

Pemerintah melalui Keputusan Presiden dan Keputusan Menteri Perindustrian dan Perdagangan telah memberikan kemudahan kepada konsumen untuk mendapatkan hak-haknya apabila telah dirugikan oleh penjual. Misalnya, Keputusan Presiden Nomor 90 Tahun 2001 tentang Pembentukan Badan

\footnotetext{
36 Innosentius Samsul, Hukum Perlindungan Konsumen (FH Pascasarjana UI 2003) 22.

37 Samsul, Perlindungan Konsumen, Kemungkinan penerapan Tanggung Jawab Mutlak (n 19$) 227$.

$38 \quad$ Nur dan Prabowo (n 35) 195.
} 
Penyelesaian Sengketa Konsumen (BPSK), Keputusan Menteri Perindustrian dan Perdagangan Nomor 301/MPP/Kep/10/2001 tentang Pengangkatan Pemberhentian Anggota Badan Penyelesaian Sengketa Konsumen (BPSK), serta Keputusan Menteri Perindustrian dan Perdagangan Nomor 350/MPP/Kep/12/2001 tentang Pelaksanaan Tugas dan Wewenang Badan Penyelesaian Sengketa Konsumen (BPSK).

Pada saat ini, Indonesia sebenarnya dapat menerapkan doktrin tanggung jawab mutlak (strict liability) pada proses penyelesaian sengketa konsumen, termasuk dalam jual beli melalui daring, karena dalam jual beli daring kemungkinan besar konsumen lebih banyak dirugikan oleh penjual. Oleh karena itu, sudah sepantasnya konsumen (masyarakat) mendapatkan perlindungan hukum secara maksimal akibat posisinya yang semakin lemah di hadapan penjual. Untuk itu, diperlukan adanya keberanian dari konsumen untuk melakukan pengaduan atau gugatan kepada penjual apabila konsumen telah dirugikan saat melakukan jual beli daring. Apabila konsumen ingin menyelesaikan melalui jalur di luar pengadilan, konsumen dapat menghubungi BPSK. Apabila konsumen ingin menyelesaikan melalui jalur pengadilan, konsumen dapat berpijak pada UUPK.

Mengingat pada jual beli daring posisi konsumen lebih lemah dibandingkan penjual, maka UUPK seharusnya dapat menjadi payung hukum yang dapat melindungi hak-hak konsumen. Namun sayangnya, UUPK saat ini belum dapat memberikan payung hukum secara maksimal kepada konsumen, karena di dalamnya belum menjelaskan secara detail prinsip tanggung jawab mutlak yang dapat menyelesaikan secara memuaskan sengketa konsumen, terutama dari pihak konsumen yang dirugikan. Oleh karena itu, pemerintah diharapkan bersedia melakukan revisi terhadap UUPK, yang didalamnya memuat tanggung jawab mutlak penjual, sehingga penjual memiliki etiked yang baik dalam menjual produknya, dan hal ini dapat mendorong persaingan yang sehat dalam berusaha. ${ }^{39}$

Berkaitan dengan prinsip tanggung jawab mutlak, Afrilia dan Primadianti menjelaskan bahwa di Indonesia pemberlakuan prinsip tanggung jawab mutlak (strict liability) belum dapat diterapkan pada semua bidang usaha atau semua produk, namun baru dapat diterapkan pada kelompok penjual atau produk tertentu. Kelompok usaha atau produk tertentu yang dimaksud adalah: (a) produk yang memiliki risiko terkait pengunaan produk; (b) tingkat kelalaian yang telah dilakukan oleh penjual; (c) produk digunakan secara massal. Selain itu, kelompok penjual yang termasuk kelompok konglomerasi adalah kelompok yang mutlak harus dibebankan atas prinsip tanggung jawab mutlak, karena kelompok ini merupakan penjual besar dan telah memiliki sistem yang baik dalam menjalan usahanya. Pengecualian ini bukan merupakan bentuk diskriminasi, tetapi hal tersebut merupakan bentuk apresiasi dan penghargaan yang harus ditunjukkan oleh penjual besar terhadap konsumennya. Selain itu, penjual dapat dijadikan contoh atau teladan yang baik bag para penjual menengah dan kecil dalam hal taat hukum, standarisasi produk, pelayanan konsumen, tanggung jawab atas produk dan sebagainya. Hal ini ke depan diharapkan dapat mendorong perkembangan industri yang sehat. 40

$39 \quad$ Afrilia dan Sulistyaningrum (n 25) 4999.

$40 \quad$ Afrilia dan Sulistyaningrum (n 25) 4999. 
Ari Wahyudi Hertanto dalam tulisannya menyimpulkan bahwa:

a. Konsumen maupun produsen serta instansi pemerintah, penegah hukum belum memiliki pemahaman yang sama dan memadai tentang product liability dan strict liability.

b. Kondisi belum dimilikinya pemahaman yang memadai tentang product liability dan strict liability ditunjang dengan kurang efektifnya keberlakuan ketentuan hukum perlindungan konsumen di kalangan masyarakat Indonesia, dan masih banyak oknum-oknum yang tidak bertanggung jawab dan memanfaatkan keadaan yang tidak kondusif ini semata-mata demi keuntungannya.

c. Meskipun telah berlaku UUPK, tetapi seringkali perkara yang diajukan ke pengadilan masih menggunakan ketentuan-ketentuan yang ada pada KUH Perdata. Hal ini mengindikasikan bahwa aparat penegak hukum belum memiliki pengetahuan yang memadai tentang dalil-dalil yang terdapat dalam UUPK untuk dipergunakan sebagai dasar gugatan dalam perkara sengketa konsumen.

d. Indonesia tidak memiliki payung hukum yang berlaku pada tingkat regional, dan masih termasuk sebagai negara berkembang dengan berbagai permasalahan sosial masyarakat yang sedemikian kompleks, dengan di satu sisi menginginkan adanya perubahan yang lebih baik tetapi resistensi terhadap perubahan tersebut juga sangat besar yang berdampak pada terhambatnya kemajuan yang dicita-citakan. ${ }^{41}$

Walaupun di Indonesia telah berlaku UUPK, namun kenyataan di lapangan masih banyak penyelesaian permasalahan sengketa konsumen yang seringkali muncul yang diajukan dengan menggunakan pasal-pasal yang terdapat pada KUH Perdata. Hal ini dapat mengindikasikan bahwa masih adanya penegak hukum yang kurang memahami UUPK sebagai dasar penyelesaian sengketa konsumen. Selain itu, juga belum ada persepsi yang sama di antara aparat penegak hukum tentang dalil-dalil yang ada dalam UUPK. Di Indonesia juga masih sulit menemukan perkara konsumen terkait dengan product liability atau strict liability, karena para pihak yang bersengketa umumnya menggunakan jalur pengadilan perdata umum, dan bukan melalui Lembaga Penyelesaian Sengketa Konsumen (LPSK). ${ }^{42}$

Penyelesaian sengketa yang terjadi dalam perjanjian jual beli secara transaksi elektronik apabila ada pihak yang dirugikan yaitu pertama dengan cara damai. Namun, apabila tidak dapat ditempuh dengan cara damai maka pihak konsumen dapat menuntut penjual sebagaimana disebutkan dalam Pasal 45 UUPK menyatakan bahwa penyelesaian sengketa atas wanprestasi dapat diselesaikan secara litigasi dan non litigasi. 43

Lembaga yang diharapkan dapat berperan penting untuk melindungi masyarakat/konsumen adalah bukan hanya lembaga peradilan yang bersifat litigasi yang berada pada peradilan umum tapi lembaga nonlitigasi seperti Badan Penyelesaian Sengketa Konsumen (BPSK) dan lembaga arbitrase lainnya. Melalui

41 Ari Wahyudi Hertanto, 'Urgensi Pengaturan Strict Liability dalam Rancangan Amandemen Undang-Undang Perlindungan Konsumen' (2011) 41 (1) Jurnal Hukum dan Pembangunan 1.

42 Afrilia dan Sulistyaningrum (n 25) 4960.

43 Desy Ary Setyawati, Dahlan, dan M. Nur Rasyid, 'Perlindungan Bagi Hak Konsumen dan Tanggung Jawab Pelaku Usaha dalam Perjanjian Transaksi Elektronik' (2017) 1 (3) Syiah Kuala Law Journal 33, 50. 
ODR salah satu alternatif penyelesain sengketa transaksi e-commerce, ODR lahir dari sinergisitas antara Alternative Disputes Resolution (ADR) dan Information of Computer Technology (ICT) sebagai metode atau langkah untuk menyelesaikan sengketa yang timbul dalam proses online yang mana penyelesaian secara litigasi sangat tidak memungkinkan. Jika kasus e-commerce lebih mengarah lintas batas Negara di ASEAN, maka bisa menggunakan ACCP karena sesuai amanat yang dikembangkan dalam roadmap MEA mengenai perlindungan konsumen. ${ }^{44}$

Di Indonesia, prinsip strict liability apabila dimasukkan dalam perundangundangan memiliki implikasi dan konsekuensi yang masih dipandang memberatkan pihak penjual. Untuk itu, apabila prinsip ini akan diberlakukan di Indonesia, ada beberapa aspek yang perlu menjadi pertimbangan, yaitu: (1) pemberlakuan prinsip strict liability hanya diperuntukan kepada kelompok penjual yang besar (konglomerasi); (2) produk yang mengandung bahan-bahan berbahaya; (3) intensitas kelalaian yang telah dilakukan oleh penjual sudah tinggi berkaitan dengan standar kualitas produk; (4) produk digunakan secara massal oleh masyarakat; (5) produk yang langsung bersentuhan dengan konsumen.

Pengaturan e-commerce yang diharapkan dimasa yang akan datang, yaitu undang-undang tentang e-commerce harus mengatur tentang kewajiban bagi penjual untuk memberikan identitasnya dengan jelas, saat mencantumkan spesifikasi produk pada halaman website harus jelas secara detil, mekanisme pembayaran jelas dan pasti untuk menghindari kesalahan pembayaran dan mekanisme pengiriman jelas cara pengiriman untuk memberikan kepastian kapan dan bagaimana barang diterima konsumen. ${ }^{45}$

\section{PENUTUP}

Berdasarkan uraian yang telah dipaparkan dapat ditarik kesimpulan bahwa produk dengan cacat tersembunyi yang dijual oleh penjual melalui jual beli daring menjadi tanggung jawab mutlak penjual dalam rangka memberikan perlindungan hukum kepada konsumen. Hal ini karena dalam jual beli melalui daring, posisi konsumen lebih lemah dibandingkan penjual. Selain itu, produk dengan cacat tersembunyi dapat membahayakan diri konsumen dan juga harta benda konsumen. Tanggung jawab mutlak penjual telah diatur pada Pasal 19 UUPK. Namun ketentuan yang ada dalam UUPK tersebut belum mengelaborasi secara rinci tanggung jawab mutlak tersebut. Pada UUPK dinyatakan bahwa konsumen yang dapat membuktikan bahwa pelaku usaha (penjual) telah melakukan kelalaian atas produk yang dijual, maka kepada penjual tersebut dapat dipersalahkan dan dimintai tanggung jawabnya atas produk yang dijual. Selanjutnya Pasal 1365 dan Pasal 1865 KUH Perdata juga menyatakan bahwa tanggung jawab produsen (penjual) untuk memberikan ganti rugi kepada pihak yang dirugikan, setelah pihak yang menderita kerugian tersebut dapat membuktikan bahwa kerugian tersebut akibat disebabkan oleh produk cacat tersembunyi yang telah dilakukan atas kelalaian penjual.

\footnotetext{
$44 \quad$ Arfian Setiantoro, Fayreizha Destika Putri, Anisah Novitarani, dan Rinitami Njatrijani, 'Urgensi Perlindungan Hukum Konsumen dan Penyelesaian Sengketa E-Commerce di Era Masyarakat Ekonomi Asean' (2018) 7 (1) Jurnal Rechts Vinding 1, 15.

45 Margaretha Rosa Anjani, dan Budi Santoso, "Urgensi Rekonstruksi Hukum E-Commerce Di Indonesia' (2018) 1 (14) Jurnal Law Reform 89, 102.
} 
Berkaitan dengan uraian di atas, maka salah satu alternatif solusi atau saran yang dapat diberikan adalah melakukan perubahan terhadap UUPK. Pokok perubahan tersebut adalah pengaturan secara rinci tentang prinsip tanggung jawab mutlak. Hal ini sangat relevan supaya perlindungan konsumen dalam jual beli daring melalui prinsip tanggung jawab mutlak dapat lebih implementatif.

\section{DAFTAR REFERENSI}

\section{Buku}

Barkatullah AH, Hak-hak Konsumen (Nusamedia 2010).

Kristiyanti CTS, Hukum Perlidungan Konsumen (Sinar Grafika 2011).

Mertokusumo S, Penemuan Hukum, Sebuah Pengantar (Liberty 2009).

Miru A dan Yodo S, Hukum Perlindungan Konsumen (Grafindo Persada 2014).

Patrick P, Dasar-dasar Hukum Perikatan (Perikatan yang Lahir dari Perjanjian dan Undang Undang) (Mandar Maju 2014).

Rajagukguk E, dkk, Hukum Perlindungan Konsumen (Mandar Maju 2000).

Samsul I, Hukum Perlindungan Konsumen (FH Pascasarjana UI 2003).

---------, Perlindungan Konsumen, Kemungkinan penerapan Tanggung Jawab Mutlak (FH Pascasarjana UI 2004).

Saragih D (tjm), Pokok-pokok Hukum Perikatan (Universitas Airlangga 2005).

Shidarta, Hukum Perlindungan Konsumen Indonesia (Grasindo 2004).

Susanto H, Hak-hak Konsumen Jika Dirugikan (Visi Media 2008).

\section{Jurnal}

Afrilia D dan Sulistyaningrum HP, 'Implementasi Prinsip Strict Liability (Prinsip Tanggung Jawab Mutlak) dalam Penyelesaian Sengketa Konsumen' (2017) 24 (3) Simbur Cahaya.

Anjani MR, dan Santoso B, "Urgensi Rekonstruksi Hukum E-Commerce Di Indonesia' (2018) 1 (14) Jurnal Law Reform.

Fitriah, 'Tanggung Jawab Produk Dalam Transaksi E-Commerce' (2021) 19 (1) Solusi.

Hertanto AW, 'Urgensi Pengaturan Strict Liability dalam Rancangan Amandemen Undang-Undang Perlindungan Konsumen’ (2011) 41 (1) Jurnal Hukum dan Pembangunan.

Holijah, 'Pengintegrasian Urgensi dan Eksistensi Tanggung Jawab Mutlak Produk Barang Cacat Tersembunyi Pelaku Usaha Dalam Undang-Undang Perlindungan Konsumen di Era Globalisasi' (2014) 14 (1) Jurnal Dinamika Hukum.

Nur YH dan Prabowo DW, 'Penerapan Prinsip Tanggung Jawab Mutlak (Strict Liability) Dalam Rangka Perlindungan Konsumen' (2011) 5 (2) Buletin Ilmiah Litbang Perdagangan. 
Pariadi D, 'Pengawasan E Commerce dalam Undang-Undang Perdagangan dan Undang-Undang Perlindungan Konsumen' (2018) 4 (3) Jurnal Hukum \& Pembangunan.

Setiantoro A, Putri FD, Novitarani A, dan Njatrijani R, 'Urgensi Perlindungan Hukum Konsumen dan Penyelesaian Sengketa E-Commerce di Era Masyarakat Ekonomi Asean' (2018) 7 (1) Jurnal Rechts Vinding.

Setyawati DA, Dahlan, dan Rasyid MN, 'Perlindungan Bagi Hak Konsumen dan Tanggung Jawab Pelaku Usaha dalam Perjanjian Transaksi Elektronik' (2017) 1 (3) Syiah Kuala Law Journal.

Spacone AC, The Emergency of Strict Laibility: A Historical Perspective and Other Consideration Including Senate 100' dalam Holijah, 'Pengintegrasian Urgensi dan Eksistensi Tanggung Jawab Mutlak Produk Barang Cacat Tersembunyi Pelaku Usaha Dalam Undang-Undang Perlindungan Konsumen di Era Globalisasi' (2014) 14 (1) Jurnal Dinamika Hukum.

Syafriana R, 'Perlindungan Konsumen Dalam Transaksi Elektronik' (2016) 1 (2) De Lega Lata.

Triasih D, B.Rini Heryanti, dan Endah Pujiastuti, 'Optimalisasi Perlindungan Hukum Bagi Konsumen Dalam Perjanjian Jual Beli Online’ (2019) 9 (2) Humani: Hukum dan Masyarakat Madani.

Verschoor D, 'Similarities and Differences between Air and Space Law, Primarily in the Field of Private International Law' dalam Holijah, 'Pengintegrasian Urgensi dan Eksistensi Tanggung Jawab Mutlak Produk Barang Cacat Tersembunyi Pelaku Usaha Dalam Undang-Undang Perlindungan Konsumen di Era Globalisasi' (2014) 14 (1) Jurnal Dinamika Hukum.

\section{Seminar}

Banu Ariyanto, 'Perlindungan Konsumen Akibat Produk Cacat Tersembunyi dalam Transaksi Jual Beli Online' (Seminar Nasional \& Call For Paper UNS 2018: Pembangunan Hukum Nasional dan Hak Asasi di Bidang Sumber Daya Alama dalam Rangka Membangun Negara Indonesia yang Sejahtera 2018).

\section{Website}

Agustin Setyo Wardani, 'Marak Penipuan Online Shop di Medsos, Hati-Hati Modusnya Makin Canggih' (Liputan6, 17 Januari 2020) <https://www. liputan6.com/tekno/read/4157301/headline-marak-penipuan-online-shopdi-medsos-hati-hati-modusnya-makin-canggih> accessed 10 Juli 2020.

Pramdia Arhando Julianto, 'Toko Online Paling Banyak Diadukan Konsumen ke YLKI, Ini Daftarnya' (Kompas, 19 Januari 2020) <https://ekonomi. kompas.com/read/2018/01/19/171756726/toko-online-paling-banyak-dia dukan-konsumen-ke-ylki-ini-daftarnya?page=all> accessed 10 Juli 2020 .

\section{Perundang-Undangan}

Kitab Undang-Undang Hukum Perdata. 
Undang-Undang Nomor 8 Tahun 1999 tentang Perlindungan Konsumen.

Undang-Undang Nomor 11 Tahun 2008 tentang Informasi dan Transaksi Elektronik.

Undang-Undang Nomor 19 tahun 2016 tentang Perubahan atas Undang-Undang Nomor 11 tahun 2008 tentang Informasi dan Transaksi Elektronik.

Peraturan Pemerintah Nomor 82 Tahun 2012 tentang Penyelenggaraan Sistem dan Transaksi Elektronik. 
